\title{
AGENDA SETTING PENYEBARAN HOAKS DI MEDIA SOSIAL
}

\author{
Christiany Juditha \\ Balai Pengembangan Sumber Daya Manusia dan Penelitian Komunikasi dan Informatika Manado \\ Jl. Pumorrow 76, Kota Manado, Sulawesi Utara, 95126, Indonesia \\ No. Telp./HP: (0431)847129 \\ E-mail: christiany.juditha@kominfo.go.id
}

Naskah diterima pada tanggal 5 September 2019 direvisi tanggal 3 Oktober 2019 disetujui tanggal 18 Oktober 2019

\section{AGENDA SETTING OF SPREADING HOAX IN SOCIAL MEDIA}

\begin{abstract}
The purpose of this study is to get an overview of the agenda-setting for the spread of hoax on social media. The method used is quantitative content analysis. The results found that there were three themes of the most prominent hoax issues, namely politics, health, and governance issues. In this case, the media setting agenda on hoax was formed by the users of social media itself. Hoax themes about politics such as Elections have increased in a certain period because social media users or netizens have relatively the same concentration and attention about it. There have also been attempts by certain parties to neutralize a theme hoax for a specific purpose, such as to overthrow each presidential candidate who is fighting in the Election process, including to topple incumbent presidential candidates who are still in power. Likewise, with a content hoax, the media agenda formed on social media represents the interests of netizens. Even in health hoax content that includes the most hoax content, the agenda of social media settings is built because netizens consider the content important to be immediately known by other audiences regardless of whether or not the content is true.
\end{abstract}

Keywords: agenda setting, hoax, social media.

\begin{abstract}
Abstrak. Tujuan dari penelitian ini adalah untuk mendapatkan gambaran tentang agenda setting penyebaran hoaks di media sosial. Metode yang digunakan adalah analisis isi kuantitatif. Hasil penelitian menemukan bahwa terdapat tiga tema isu hoaks yang paling menonjol yaitu politik, kesehatan, dan isu pemerintahan. Dalam hal ini, agenda setting media tentang hoaks dibentuk oleh para pengguna media sosial itu sendiri. Tema hoaks tentang politik seperti pemilu meningkat dalam kurun tertentu, dikarenakan pengguna media sosial atau netizen memiliki konsentrasi dan perhatian yang relatif sama tentang hal tersebut. Ada juga upaya dari pihakpihak tertentu untuk memviralkan sebuah tema hoaks untuk tujuan tertentu semisal untuk menjatuhkan masing-masing kandidat presiden yang sedang bertarung dalam proses pemilu. Termasuk untuk menjatuhkan kandidat presiden petahana yang masih berkuasa. Begitu pula dengan konten hoaks, agenda media yang terbentuk di media sosial merepresentasikan kepentingan para netizen. Bahkan pada konten hoaks bidang kesehatan yang termasuk konten hoaks terbanyak, agenda setting media sosial yang terbangun karena netizen menganggap konten tersebut penting untuk segera diketahui oleh khalayak lainnya terlepas dari benar tidaknya konten tersebut.
\end{abstract}

Kata kunci: agenda setting, hoaks, media sosial. 


\section{PENDAHULUAN}

Hoaks atau berita bohong atau berita tidak benar saat ini semakin marak peredarannya melalui internet. Jika dahulu penyebaran berita tidak benar dalam bentuk spanduk, poster, selebaran, dan sejenisnya, kini di era digital penyebaran hoaks melalui media sosial maupun pesan instan.

Penyebaran hoaks menggunakan media lama, sangat mudah dibersihkan dan dilupakan orang, sementara melalui media baru tidak akan selesai begitu saja. Bahkan modus yang sering terjadi saat ini, begitu hoaks diproduksi oleh pihak tertentu, kemudian disebarkan melalui media sosial yang akan terus meninggalkam jejak digital tanpa diverifikasi terlebih dulu.

Berbagai pihak berpendapat bahwa penyebaran hoaks sangat rentan terpapar oleh masyarakat karena mudahnya dikonsumsi. Apalagi saat ini pengguna media sosial dan pesan instan dari tahun ke tahun semakin meningkat. Indonesia menjadi salah satu negara dengan pengguna media sosial terbesar di dunia. Penelitian yang dilakukan We Are Social, menyebutkan bahwa rata-rata orang Indonesia menghabiskan tiga jam lebih sehari untuk mengakses media sosial. Total populasi Indonesia sebanyak 265,4 juta jiwa, sedangkan pengguna aktif media sosialnya mencapai 130 juta dengan penetrasi 49 persen (Pertiwi, 2018).

Media sosial dan pesan instan (aplikasi chatting) merupakan dua media yang paling banyak digunakan dalam penyebaran hoaks. Masyarakat Telematika (MASTEL) (2017) dalam hasil surveinya tentang "Wabah Hoax Nasional" menyebutkan bahwa saluran yang paling banyak digunakan dalam penyebaran hoaks adalah melalui media sosial (Facebook, Twitter, Instagram, dan Path) yang mencapai $92,40 \%$ menyusul aplikasi chatting seperti Whatsapp, Line, Telegram yaitu sebesar $62,80 \%$, sementara melalui situs web, hanya mencapai $34,90 \%$.

Sementara riset yang dilakukan DailySocial.id yang bekerjasama dengan Jakpat Mobile Survey Platform terhadap 2032 pengguna smartphone di berbagai penjuru Indonesia, menyimpulkan saluran terbanyak penyebar berita bohong atau hoaks dijumpai di media sosial yaitu persentasenya di Facebook (82,25\%), WhatsApp (56,55\%), dan Instagram $(29,48 \%)$. Hasil penelitian ini juga menyebutkan bahwa sebanyak $44,19 \%$ responden tidak yakin memiliki kepiawaian dalam mendeteksi berita hoaks, sebanyak $51,03 \%$ responden memilih untuk berdiam diri (dan tidak percaya dengan informasi) ketika menemui hoaks, sekitar $72 \%$ responden memiliki kecenderungan untuk membagikan informasi yang mereka anggap penting serta sebagian besar responden (73\%) selalu membaca seluruh informasi. Namun hanya $55 \%$ yang selalu memverifikasi keakuratan atau fact check (Sakti, 2018).

Sementara itu, Kementerian Kominfo merilis hasil temuan mereka sepanjang tujuh bulan sejak Agustus 2018 hingga Februari 2019, terdapat 771 hoaks yang berhasil teridentifikasi. Temuan ini juga menyebutkan bahwa jumlah konten hoaks yang beredar di media online terus meningkat dari bulan ke bulan. Bulan Agustus 2018, hanya 25 informasi hoaks yg diidentifikasi hingga bulan Februari 2019 mencapai 353 konten hoaks (Kominfo, 2019).

Melihat hasil temuan Kominfo terbaru tentang hoaks ini, maka menarik untuk dilakukan kajian secara lebih mendalam tentang isi konten hoaks yang paling banyak beredar melalui media sosial belakangan ini. Mengapa ada konten dengan tema-tema tertentu yang cenderung lebih tinggi dari tema lainnya. Apa tujuan dan motif di balik penyebaran konten hoaks dan bagaimana kekuatan agenda setting hoaks tersebut. Seperti diketahui bahwa agenda setting media sosial bisa terbentuk oleh orang-orang awam (pengguna internet) yang memiliki kesamaan interes terhadap sebuah isu. Warganet dapat ikut menentukan isu-isu penting bagi pembicaraan publik. Bahkan tidak sedikit media massa konvensional memanfaatkan agenda media sosial untuk pemberitaan mereka. Karena itu berdasarkan latar belakang tersebut di atas maka rumusan masalah dari penelitian ini adalah bagaimana agenda setting penyebaran hoaks di media sosial?. Tujuan dari penelitian ini adalah untuk mendapatkan gambaran tentang agenda setting penyebaran hoaks di media sosial. 
Vargo \& Guo (2017) pernah melakukan penelitian dengan judul "The Agenda-Setting Power of Fake News: A Big Data Analysis of The Online Media Landscape from 2014 to 2016". Studi ini meneliti tentang kekuatan pengaturan agenda (agenda setting) berita palsu di media online dari 2014 hingga 2016. Meskipun penelitian ini mengonfirmasi bahwa konten dari situs web berita palsu meningkat, namun situs ini tidak menggunakan kekuatan agenda setting yang berlebihan. Sebaliknya, berita palsu memiliki jalinan hubungan yang rumit dengan media partisan online, baik dalam menanggapi maupun menetapkan agenda isu. Pada tahun 2016, media partisan tampaknya sangat rentan terhadap agenda palsu berita. Penelitian lain juga dilakukan oleh Salman et al. (2016) dengan judul "Social Media and Agenda Setting: Implications on Political Agenda". Penelitian ini menjelaskan bahwa sejak munculnya internet, informasi politik kini berada di tangan setiap warga Malaysia, terutama mereka yang tinggal di daerah perkotaan dan memiliki akses internet. Orang tidak perlu memiliki media tradisional seperti radio, televisi, atau koran untuk memahami apa yang terjadi dalam pengaturan politik di Malaysia. Ini karena media sosial, terutama Facebook dan Twitter telah membuat akses informasi begitu mudah bagi populasi yang lebih besar. Tujuan dari studi ini adalah untuk mengeksplorasi peran media sosial sebagai mekanisme pengaturan agenda (agenda setting) dalam skenario politik Malaysia. Media sosial telah digunakan oleh publik untuk mengungkapkan keprihatinan dan keluhan mereka tentang masalah yang menyangkut kesejahteraan mereka yang mungkin tidak berani dilaporkan atau disiarkan oleh media tradisional. Pengaturan agenda perlu dimasukkan kembali ke dalam, karena agenda publik mengambil panggung sentral melalui media baru/sosial. Dengan demikian, ini menyiratkan, model agenda setting dapat diperpanjang atau direnovasi untuk memasukkan media sosial baru karena pengaruhnya terhadap agenda publik. Implikasi lebih lanjut dari ini adalah bahwa para politisi harus terus mengikuti perkembangan di media sosial sehingga mereka akan memahami masalah saat ini yang menjadi perhatian besar bagi masyarakat.

"Agenda Setting through Social Media: The Importance of Incidental News Exposure and Social Filtering in the Digital Era" juga merupakan judul penelitian yang dilakukan oleh Feezell (2017). Penelitian ini menyebutkan bahwa model konvensional dari penetapan agenda menyatakan bahwa media arus utama memengaruhi agenda publik dengan mengarahkan perhatian audiens, dan menganggap penting untuk isu-isu tertentu. Namun, selektivitas dan fragmentasi audiens yang meningkat di lingkungan media digital saat ini mengancam kekuatan agenda setting tradisional media massa. Studi ini menyelidiki apakah media arus utama dapat memengaruhi agenda publik ketika disalurkan melalui media sosial. Dengan memanfaatkan eksperimen orisinal, longitudinal, penelitian ini menguji apakah terpapar dengan informasi politik melalui Facebook menghasilkan efek agenda setting dengan meningkatkan kepentingan peserta yang dirasakan dari masalah kebijakan tertentu. Temuan menunjukkan bahwa peserta yang terpapar informasi politik di Facebook menunjukkan peningkatan tingkat arti penting isu yang konsisten dengan masalah yang dibagikan dibandingkan dengan peserta yang tidak ditunjukkan informasi politik. Penelitianpenelitian yang dibahas ini banyak menitikberatkan pada studi agenda setting namun pada media online (situs berita) dengan isu berita palsu (fake news). Penelitian lain juga melakukan uji pengaruh antara agenda setting dari media sosial/media online dengan media konvensional. Sementara penelitian yang dikaji ini akan melihat secara lebih spesifik kecenderungan agenda setting yang terbentuk di media sosial khususnya yang membahas isu hoaks. Penelitian dengan topik ini belum pernah dilakukan sebelumnya sehingga dianggap penting untuk dilakukan.

\section{LANDASAN KONSEP}

Teori agenda setting dicetuskan pertama kali oleh McCombs (2014) dengan didasari oleh asumsi bahwa media massa 
memiliki kekuatan untuk memengaruhi agenda media kepada agenda publik. Publik cenderung menilai sesuatu itu penting sebagaimana media massa menganggap hal tersebut penting. Jika media massa menganggap suatu isu itu penting, maka publik juga akan menganggapnya penting (Griffin, 2012). Teori ini menawarkan dasar pemikiran di mana penjelasan atau pemaparan saja tidak cukup, konten media perlu dibuat menonjol sebelum diproses dan diterima oleh publik. Semakin sering media menyajikan suatu isu atau topik, semakin menonjol pula isu tersebut dan semakin besar pula perhatian publik terhadap isu tersebut.

Landasan perspektif agenda setting yang diletakkan oleh McCombs \& Shaw bertitik tolak dari gagasan peran media massa sebagai pembentuk opini publik (Tamburaka, 2012). Ada korelasi yang kuat dan signifikan antara apa yang diagendakan oleh media massa dan apa yang menjadi agenda publik. Penyusunan agenda setting menjelaskan tiga proses yaitu pertama, berita diseleksi, diolah, dan disajikan yang dikenal dengan proses gatekeeping. Kedua, menghasilkan agenda media. Ketiga, agenda media memengaruhi pendapat publik tentang isu yang ditonjolkan (Prabowo, 2016). Teori agenda setting berfokus pada proposisinya, yakni agenda media, agenda publik, dan isu. Dearing, J. W., \& Rogers (1996) mendefinisikan agenda media sebagai daftar isu dan peristiwa pada suatu waktu tertentu yang disusun sesuai dengan urutan kepentingannya. Agenda media terdiri dari pokok persoalan, aktor, peristiwa, anggapan, dan pandangan yang memanfaatkan waktu dan ruang dalam publikasi yang tersedia untuk disampaikan pada publik (Merheim, 1986).

Agenda media menurut Mannheim dalam Nurudin (2009) berkaitan dengan beberapa dimensi yaitu: 1). Visibilitas, adalah jumlah dan tingkat menonjolnya berita; 2). Audience salience, yaitu tingkat menonjol bagi khalayak, relevansi isi berita dengan kebutuhan khalayak; 3). Valensi, yakni menyenangkan atau tidak menyenangkan cara pemberitaan bagi suatu peristiwa (Merheim, 1986). Agenda media, menurut McCombs \& Shaw (1972), dapat dilihat dari aspek apa saja yang coba ditonjolkan oleh pemberitaan di suatu media. Penentuan atau seleksi yang dilakukan media sehari-harinya juga didasarkan pada politik pemberitaan masingmasing media yang merupakan interpretasi subjektif media massa, termasuk para pekerja media yang terikat dengan situasi organisasi tempat mereka bernaung. Agenda publik berhubungan dengan isu-isu yang digambarkan dalam konten atau isi media dan yang kemudian diprioritaskan oleh publik. Kebanyakan isu bisa masuk dalam agenda publik melalui proses repetisi pesan, publik mengenalinya kemudian menempatkannya dalam kepentingannya. Sehingga agenda publik dapat diartikan sebagai daftar dari isu yang telah disusun publik menurut kepentingannya pada suatu kurun waktu tertentu.

Agenda setting media konvensional sedikit bergeser sejak media baru mulai banyak digunakan seperti media online dan media sosial dimana lanskap media modern dihuni oleh bloggers, jurnalis warga (citizen journalists), pengguna media sosial, seperti Facebook dan Twitter, yang setara dengan media massa pada umumnya. Kini, siapapun bisa menjadi simpul dalam proses produksi media.

Menurut teori, media massa memengaruhi prioritas atau kepentingan publik dengan menyalurkan perhatian mereka kepada isu-isu tertentu. Hal ini menunjukkan bahwa media sosial dapat ikut menentukan isu-isu penting bagi pembicaraan publik. Media massa konvensional mulai menerima perubahan yang terjadi, menjadi lebih fleksibel, beradaptasi terhadap perubahan dalam tataran media, bahkan memanfaatkan keberadaan media sosial itu sendiri. Menurut Messner dan Distato dalam Damaris (2016), media konvensional rutin mengutip blog sebagai sumber, dan juga sebaliknya. Blog kebanyakan bergantung pada media konvensional untuk memperoleh informasi. Kini keberadaan media massa dan media sosial saling memengaruhi, bahkan menguntungkan satu sama lain (Metei, 2010).

Media sosial dalam teori agenda setting berhubungan erat dengan agenda publik. Kini media sosial memiliki posisi yang bisa menimbulkan beberapa aksi yang erat hubungannya dengan teori agenda setting. 
Media sosial memiliki koneksi antara pengguna dan saling menukarkan informasi. Media sosial tidak bersifat satu arah tapi sebaliknya, bersifat dua arah. Sehingga informasi yang disampaikan kemudian dikembangkan dan memiliki respon aktif sehingga agenda yang terjadi dapat dilihat secara realistis. Melalui media sosial seluruh pengguna mendeskripsikan pesan yang diterima dan menindaklanjuti dengan menggunakan respon aktif seperti berkomentar maupun membagikan informasi tersebut. Hal ini berkaitan dengan agenda publik, media sosial membawa sebuah pengaruh bagi publik, yaitu memengaruhi kesadaran dan juga aksi. Sehingga dimensi teori agenda media menurut Mannheim dalam Nurudin (2009) yaitu visibilitas (jumlah dan tingkat menonjolnya berita), audience salience (tingkat menonjol bagi khalayak, relevansi isi berita dengan kebutuhan khalayak serta valensi (menyenangkan atau tidak menyenangkan cara pemberitaan bagi suatu peristiwa) yang digunakan dalam mengukur media konvensinal juga relevan untuk mengukur agenda media sosial.

Berbicara tentang agenda setting media dan publik tidak terlepas dari apa yang disebut dengan isu. Effendy (2005) menyebutkan bahwa isu merupakan kabar yang beredar di masyarakat yang tidak dapat dipertanggungjawabkan kebenarannya disebabkan sumbernya yang tidak jelas. Isu dapat dijabarkan dalam lima penafsiran menurut (Nasionalita, 2013), yaitu: 1) Masalah yang menjadi perhatian pribadi publik; 2) Persepsi dan penjabaran dari masalah yang dihadapi masyarakat; 3) Penyebaran tentang kemungkinan yang mesti dipilih oleh publik, setuju atau tidak setuju terhadap suatu kebijakan; 4) Suatu masalah yang mengandung pro dan kontra dalam masyarakat; dan yang ke 5) Alasan atau faktor-faktor yang menjadi penentu jalan keluar dalam suatu kesenjangan politik.

Hoaks dalam Bahasa Indonesia berarti berita bohong, informasi palsu, atau kabar dusta. Istilah hoaks ini mulai populer seiring dengan popularitas media online, terutama media sosial (Romeltea, 2014). Pellegrini (2008) mengembangkan definisi hoaks dari MacDougall dan menjelaskannya sebagai sebuah kebohongan yang dikarang sedemikian rupa oleh seseorang untuk menutupi atau mengalihkan perhatian dari kebenaran, yang digunakan untuk kepentingan pribadi, baik itu secara intrinsik maupun ekstrinsik. Sedangkan hoaks dalam KBBI (2019) memiliki arti berita bohong. Hoaks dapat diartikan sebagai sebuah pemberitaan palsu yang tidak dapat dipertanggungjawabkan kebenarannya. Chen, Yoke Yiie (2014) mendefinisikan hoaks sebagai informasi yang sesat dan berbahaya. Persepsi manusia dapat disesatkan karena hoaks, namun tetap disampaikan menjadi sebuah informasi yang dianggap benar, dan hal tersebut dapat memengaruhi orang banyak.

Seperti yang telah dijelaskan pada pendahuluan bahwa media sosial dan pesan instan adalah media yang banyak digunakan sebagai media penyebar hoaks. Karena kedua media ini memiliki karakteristik jaringan sosial. Jaringan sosial yang terbentuk karena adanya kesamaan tujuan pengirim maupun penerima pesan untuk menjelek-jelekkan pihak-pihak tertentu maupun sebaliknya yaitu direspon sebagai pembelaan objek hoaks. Sementara karakteristik sosial yang terbangun di dalamnya adalah membentuk jaringan di antara penggunanya, baik saling mengenal, maupun tidak, namun dipertemukan dalam sebuah kesamaan karekteristik sosial, yaitu sama-sama pendukung pihak tertentu dan anti pihak lainnya. Di samping itu media sosial paling mudah digunakan, dalam waktu dan tempat yang tidak terbatas (Juditha, 2018).

Karakter media baru inilah yang membuatnya penyebaran hoaks semakin masif. Pesan bermuatan hoaks dapat disebarkan, direproduksi, bahkan dimodifikasi secara digital. Penyebarannya sulit untuk dikendalikan karena ada sistem penyimpanan digital. Hoaks masih dapat diakses dan disebarkan secara online dan offline, bahkan setelah posting asli dihilangkan sekalipun, sebuah hoaks tidak dapat benar-benar dihapus. Ada begitu banyak saluran yang dapat dipakai untuk menyebarkan hoaks (Dwiyana dalam Juditha, 2018).

Nasrullah (2015a) berpendapat bahwa karakteristik media sosial adalah berjaringan, 
informatif, ada arsip, ada interaksi, gambaran simulasi sosial dan isi informasi atau konten yang diproduksi oleh pengguna. Karakteristik ini pula yang menjadikan media sosial sebagai medium penyebaran hoaks yang paling mudah dan cepat. Ismail Fahmi dalam Kadju (2019) mengatakan bahwa media sosial menjadi lahan subur bagi tumbuh kembangnya hoaks. Ada begitu banyak hoaks yang menyebar tanpa kendali dan bisa saja masyarakat dengan mudah terpapar oleh hoaks-hoaks tersebut.

Berdasarkan konsep dan teori di atas maka kerangka pemikiran dari penelitian ini terlihat di Gambar 1.

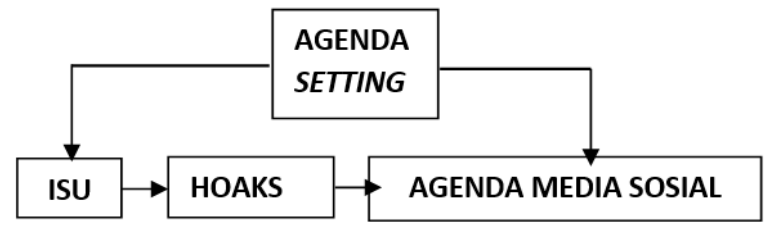

Gambar 1. Kerangka Pemikiran

Agenda setting dibentuk berdasarkan isu yang sedang beredar di masyarakat, isu ini menyangkut tentang berbagai topik namun termasuk berita/informasi hoaks berdasarkan temuan dari Kementerian Kominfo. Isu-isu yang dianggap menonjol ini kemudian disajikan dalam bentuk berita/informasi di media sosial. Karakteristik media sosial adalah bebas tanpa adanya gatekeeper, sehingga berita/informasi hoaks yang tersaring dan kemudian di-posting di media sosial terjadi sesuai dengan keinginan dari pengguna atau penyebar hoaks. Hal ini kemudian menghasilkan agenda media sosial yang dapat memengaruhi pendapat publik tentang isu hoaks yang sedang ditonjolkan.

\section{METODE PENELITIAN}

Penelitian ini dilakukan dengan menggunakan metode analisis isi kuantitatif. Holsti mendefinisikan bahwa analisis ini adalah teknik apapun yang digunakan untuk menarik simpulan melalui usaha menemukan karakteristik pesan dan dilakukan secara objektif dan sistematis (Soejono \& Abdurrahman, 1999). Analisis isi ditujukan untuk mengidentifikasi secara sistematis isi komunikasi yang tampak (manifest), dan dilakukan secara objektif, valid, reliabel, dan dapat direplikasi (Eriyanto, 2011).
Populasi dalam penelitian ini adalah hasil temuan hoaks dari Kementerian Kominfo selama tujuh bulan sejak Agustus 2018 s.d. Februari 2019 dari media sosial (Facebook, Twitter, Youtube Google, Line dan BBM). Adapun alasan tujuh bulan dilakukan kajian, karena laporan temuan hasil hoaks tim AIS Kominfo yang dirilis hanya sebanyak tujuh bulan. AIS merupakan singkatan dari (Automatic Identifications Systems) yaitu mesin pengais konten yang dimiliki oleh Kementerian Kominfo. Tujuan dari mesin ini adalah untuk menjaring/mengais konten-konten negatif termasuk hoaks, baik melalui website maupun akun media sosial. Unit analisis yang merupakan fokus riset adalah seluruh isu hoaks berbagai topik dari hasil temuan Kominfo tersebut.

Teknik pengumpulan data dalam penelitian ini adalah observasi tidak langsung (indirect observation) yakni peneliti akan meneliti produk-produk komunikasi, yaitu teks (Frey, Lawrence R, 1991). Data akan diperoleh dari data primer dan data sekunder. Data primer adalah data yang diperoleh langsung dari subjek penelitian atau alat pengambilan data langsung pada subjek sebagai sumber informasi yang dicari.

Cara menganalisis keseluruhan teks hoaks dalam penelitian ini adalah dengan menggunakan kategori agenda setting yaitu visibilitas, audience salience, dan valensi. 
Dalam penelitian digunakan pendekatan directed content analysis yang berawal dari teori sebagai guide (Lichtman, 2010). Kategori dalam penelitian ini meliputi tiga bagian dengan mengacu pada konsep agenda setting yang kemudian menghasilkan agenda media sosial yang digambarkan dalam tabel berikut ini:

Tabel 1

Kategori Agenda Setting Media Sosial Terhadap Isu Hoaks

\begin{tabular}{|c|c|c|}
\hline No. & Kategori & Keterangan \\
\hline 1. & Visibilitas & $\begin{array}{l}\text { Jumlah dan tingkat } \\
\text { menonjolnya isi hoaks }\end{array}$ \\
\hline 2. & $\begin{array}{l}\text { Audience } \\
\text { salience }\end{array}$ & $\begin{array}{l}\text { Tingkat menonjol bagi } \\
\text { khalayak, relevansi isi } \\
\text { hoaks dengan kebutuhan } \\
\text { khalayak }\end{array}$ \\
\hline 3. & Valensi & $\begin{array}{l}\text { Menyenangkan atau tidak } \\
\text { menyenangkan cara } \\
\text { penyajian isi hoaks bagi } \\
\text { suatu peristiwa. }\end{array}$ \\
\hline
\end{tabular}

Sumber: Mannheim (dalam Nurudin, 2009)

Teknik analisis data yang telah dikategorikan sebelumnya dan dimasukkan dalam lembar coding. Penghitungan data kemudian dapat dilakukan dalam distribusi frekuensi dengan bantuan mesin AIS Kominfo. Hasil penelitian diolah secara kuantitatif dengan cara mencatat frekuensi kemunculan unit analisis yang ditetapkan melalui lembar coding, kemudian disusun ke dalam tabel untuk mempermudah penelitian. Selanjutnya hasil penelitian diuraikan secara deskriptif guna membahas kecenderungan agenda media hoaks di media sosial. Data yang dikumpulkan kemudian digambarkan dalam bentuk tabel maupun grafik dan kemudian dijelaskan secara deskripsi. Hasilnya dikomparasikan dengan hasil penelitian-penelitian sebelumnya dan juga dari sumber-sumber yang berhubungan dengan hasil penelitian. Kesemuanya ini kemudian dianalisis secara deskriptif sehingga menghasilkan sebuah gambaran sebagai jawaban dari rumusan masalah yang dicari.

\section{HASIL PENELITIAN DAN PEMBAHASAN}

Kementerian Kominfo (2019) merilis hasil temuan tentang hoaks sepanjang tujuh bulan sejak Agustus 2018 hingga Februari 2019. Hasilnya terdapat 771 hoaks yang berhasil teridentifikasi. Temuan ini juga menyebutkan bahwa jumlah konten hoaks yang beredar di media online (media sosial dan website) terus meningkat dari bulan ke bulan. Bulan Agustus 2018 hanya 25 informasi hoaks yang diidentifikasi, namun pada bulan September 2018 naik menjadi 27 hoaks, sementara Oktober dan November 2018 masing-masing 53 dan 63 hoaks. Bulan Desember 2018, jumlah info hoaks terus naik menjadi 75 konten. Peningkatan jumlah konten hoaks sangat signifikan terjadi pada bulan Januari dan Februari 2019. Sebanyak 175 konten hoaks yang berhasil diverifikasi oleh Tim AIS Kemkominfo. Angka ini naik dua kali lipat di Februari 2019 menjadi 353 konten hoaks (Gambar 1). 


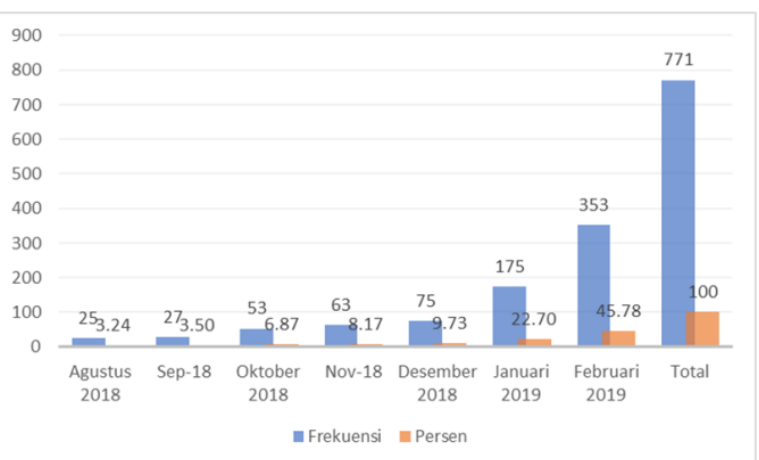

Sumber: Data diolah dari Kominfo (2019)

Gambar 1. Temuan Hoaks Keminfo

Salah satu dimensi dari agenda media menurut Mannheim dalam Nurudin (2009) adalah visibilitas. Visibilitas merupakan jumlah dan tingkat menonjolnya berita/isu. Visibilitas dari temuan Kominfo ini menunjukkan bahwa selama tujuh bulan, isu yang paling menonjol adalah isu hoaks tentang politik, menyusul kesehatan, pemerintahan, fitnah, bencana dan agama. Sementara isu hoaks tentang mitos, internasional, penipuan, perdagangan dan pendidikan tidak terlalu menonjol dibanding isu hoaks lainnya (Gambar 2).

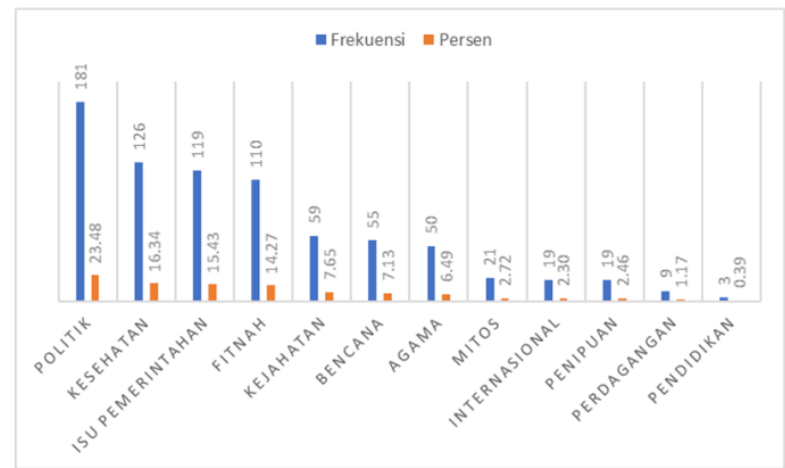

Sumber: Data diolah dari Kominfo (2019)

Gambar 2. Visibilitas Isu Hoaks

Agenda media yang lainnya adalah audience salience, yaitu tingkat menonjolnya isu hoaks bagi khalayak dan relevansi isi hoaks dengan kebutuhan khalayak. Gambar 3 menunjukkan bahwa hasil penelitian menemukan ada empat isu hoaks yang paling menonjol bagi khalayak yaitu dengan kategori tema tertentu yaitu tentang politik, kesehatan, isu pemerintahan dan fitnah.

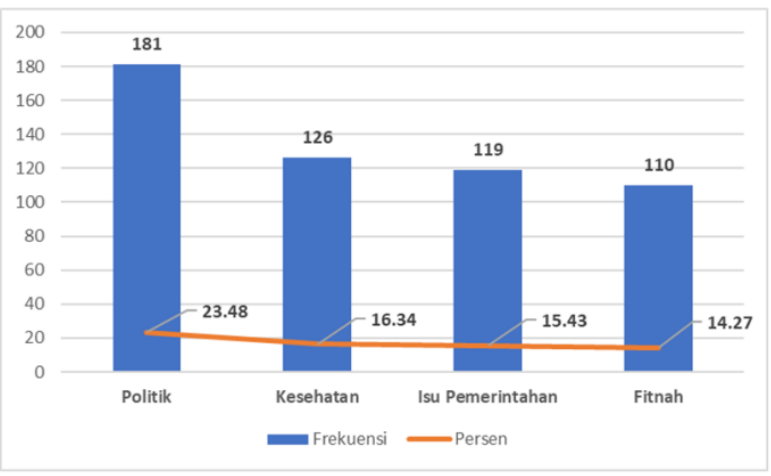

Sumber: Data diolah dari Kominfo (2019)

Gambar 3. Audience Salience Isu Hoaks 
Valensi merupakan agenda media lainnya yang memiliki arti menyenangkan atau tidak menyenangkan cara pemberitaan isu hoaks bagi suatu peristiwa. Dari hasil identifikasi konten hoaks, tema politik adalah yang terbanyak yaitu 181 konten.
Sementara jika ditelusuri lebih jauh lagi, 62 di antaranya adalah konten tentang pemilu, mengingat bahwa eskalasi masalah politik di waktu-waktu ini sangat gencar dengan persoalan pemilu (Gambar 4).

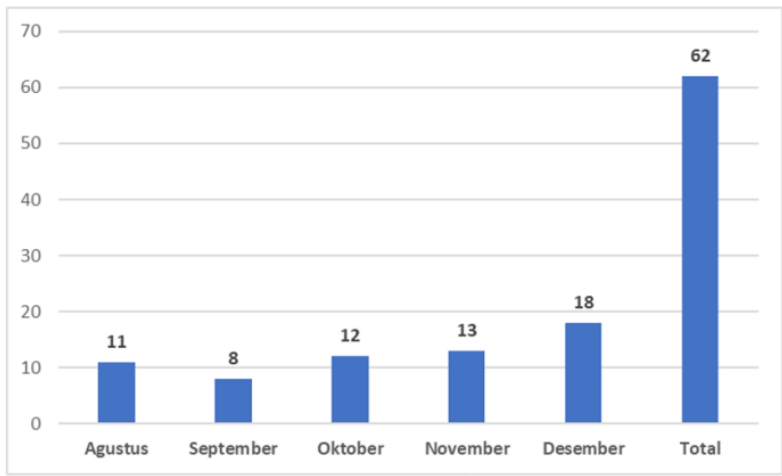

Sumber: Data diolah dari Kominfo (2019)

Gambar 4. Konten Hoaks tentang Pemilu Agustus-Desember 2018

Jika dihubungkan dengan cara penyajian konten hoaks yang menyenangkan atau tidak bagi khalayak tergantung di kubu mana penerima pesan itu memihak. Seperti diketahui akibat masalah Pemilu Presiden, masyarakat kemudian terbagi menjadi dua kubu, pendukung 01 Jokowi-Ma'ruf Amin, dan 02 Prabowo-Sandiaga Uno. Hoaks yang beredar pun tidak jauh dari pasangan calon (paslon) presiden dan wakil presiden ini. Jika konten hoaks yang menyudutkan paslon 01, maka penyajiannya dianggap tidak menyenangkan bagi para pendukungnya begitupun sebaliknya.

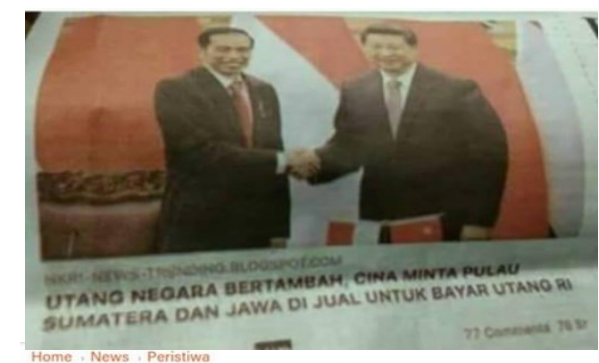

Sandiaga: Atlet Pribumi Kita Fisiknya Lemah, IQ-nya Rendah, Indonesia Gak Bakal Juara Asian Games 2018

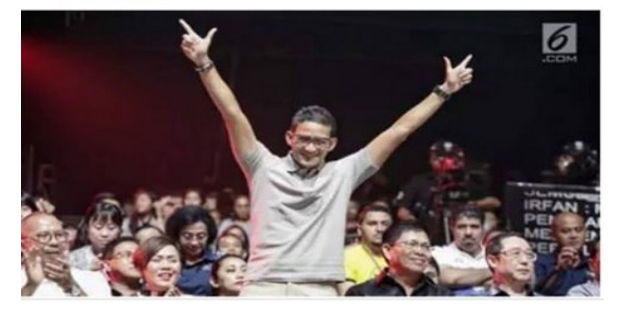

Sumber : https://turnbackhoax.id/2018

Gambar 5. Konten Hoaks tentang Pemilu (Politik)

Beberapa contoh judul konten hoaks yang terdeteksi pada bulan Agustus 2018 seperti: "Cina minta Jokowi Jual Pulau Jawa dan Sumatra", "Banser resmi dukung
Prabowo Sandi", "Survei Kemenangan Prabowo", "Pernyataan Sandiaga Tidak Yakin Indonesia Raih Juara di Asian Games 2018", "Dukungan KH Said Aqil terhadap 
Paslon Prabowo Sandiaga", "Badai Pasir Terjadi karena Spanduk \#2019gantipresiden", "Statement Sri Mulyani Tantang Pembenci Jokowi, Megawati Setuju PKI Bangkit“".

Jika memperhatikan hasil penelitian ini, dapat disimpulkan bahwa selama kurun waktu tujuh bulan sangat banyak konten hoaks yang terindentifikasi khususnya di media sosial dan pesan instan. Data ini juga dari bulan ke bulan terus meningkat hingga bulan Februari 2019. Hal ini menunjukkan bahwa wabah hoaks telah menjadi kasus yang tidak dapat dianggap sepele oleh pihak manapun termasuk oleh pemerintah. Apalagi karena dampak negatifnya sangat memengaruhi masyarakat. Sesuai yang disampaikan oleh Chen, Yong \& Ishak (2014) bahwa hoaks sebagai informasi yang sesat dan berbahaya. Persepsi manusia dapat disesatkan karena hoaks, namun tetap disampaikan menjadi sebuah informasi yang dianggap benar, dan hal tersebut dapat memengaruhi orang banyak.

Masyarakat cenderung lebih percaya kepada berita-berita yang beredar tanpa menguji kebenarannya terlebih dahulu. Tidak heran kalau hoaks yang beredar tanpa verifikasi tidak putus hingga penerima terakhir, namun terus berlanjut dibagikan kepada orang lain. Laras Sekarasih dalam Respati (2017) mengatakan orang lebih cepat percaya hoaks karena opini atau sikap seseorang yang dimiliki sama dengan informasi yang beredar tersebut. Seseorang akan menerima informasi apapun tentang seseorang, kelompok, kebijakan tertentu, serta produk, jika memang memiliki kesukaan terhadap hal-hal itu. Meskipun informasi tersebut tidak benar, tetap saja diterima tanpa melakukan telaah apakah informasi itu benar atau sebaliknya. Bagi mereka informasi tersebut layak dipercaya sehingga layak untuk disebarkan kepada orang lain.

Selanjutnnya konten dengan tema politik, kesehatan, dan isu pemerintahan adalah tiga isu yang paling mendominasi peredaran hoaks selama tujuh bulan terakhir. Bahkan tingkat penonjolan hoaks tertinggi dengan tema politik (pemilu). Salah satu alasan karena selama tujuh bulan ini persiapan Pemilu Presiden 2019 sedang hangat-hangatnya berlangsung. Apalagi salah satu kontestan pemilu adalah petahana yaitu Joko Widodo yang juga masih menjabat sebagai Presiden RI. Hoaks yang beredarpun tidak semata-mata untuk menjatuhkan Jokowi sebagai calon presiden tetapi juga sebagai pemerintah yang masih berkuasa. Hal ini dapat dilihat dari beberapa contoh judul konten hoaks antara lain "Cina Minta Jokowi Jual Pulau Jawa dan Sumatra", "Statement Sri Mulyani Tantang Pembenci Jokowi" dan lain sebagainya.

Hasil penelitian ini menunjukkan bahwa pembuat dan penyebar hoaks juga tidak menyenangi pemerintah yang berkuasa. Seperti juga yang diungkapkan oleh Christiany (2018) dalam penelitiannya "Interaksi Komunikasi Hoax di Media Sosial serta Antisipasinya" yang menyebutkan bahwa pengirim pesan hoaks merupakan orang-orang atau pihak yang tidak menyenangi pemerintah. Sedangkan penerima hoaks ini pun memiliki kesamaan pikiran (mendukung) dengan pengirim pesan. Mereka juga merupakan pendukung pihak tertentu yang berseberangan dengan objek hoaks. Hal ini dilihat dari kehadiran mereka secara maya dalam grup media sosial dan ikut menyebarkan hoaks atau memberi komentar negatif. Penerima pesan yang lain merupakan pihak yang tidak sepakat dengan pengirim pesan sehingga mereka membantah, sebagai dukungan terhadap pemerintah dan tidak setuju dengan penyebaran hoaks. Ada tujuan-tujuan tertentu untuk menjatuhkan pemerintah yang berkuasa dengan jalan merusak citra yang bersangkutan dengan penyebaran hoaks.

Tema hoaks yang juga memiliki jumlah peredaran yang tinggi adalah konten tentang kesehatan. Beberapa hasil penelitian sebelumnya juga mengungkapkan bahwa hoaks bidang kesehatan merupakan konten yang juga banyak beredar di masyarakat. Menurut survei yang dilakukan oleh seorang dokter, Ari Fahrial Syam dalam Pertiwi (2017), sebanyak 90 persen lebih informasi tentang kesehatan memiliki sumber yang tidak jelas dan tidak dapat dipertanggungjawabkan. Namun, berita tersebut menyebar dengan bebas melalui 
situs jejaring sosial maupun pesan instan (pengiriman pesan instan). Hal ini diperkuat dari penelitian Persatuan Wartawan Indonesia (PWI) yang menyebutkan bahwa hoaks terbanyak di masyarakat adalah bidang kesehatan. Berdasarkan penelitian PWI, hoaks bidang kesehatan disebarkan oleh orang-orang tanpa sengaja. Mereka menganggap informasi tersebut harus segera disampaikan karena berguna bagi orang lain. Hoaks bidang kesehatan dipandang lebih berbahaya dibanding hoaks jenis lainnya. Hal ini dikarenakan hoaks tersebut memiliki dampak fatal yang mengancam jiwa seseorang (Juditha, 2019).

Jika dihubungkan dengan agenda setting media dapat dijelaskan bahwa secara konvensional media massa menempatkan diri sebagai gatekeeper (White, 1950) yang menyeleksi berita-berita melalui proses agenda setting untuk memengaruhi agenda khalayak (McCombs dan Shaw, 1972). Namun pesatnya penggunaan internet seperti media sosial Facebook, MySpace, dan Twitter bisa dikatakan sebagai komunikasi massa dengan karakter many-to-many yang mana para anggotanya yang jumlahnya banyak menjadi audiens sekaligus sumber isi informasi (Straubhaar, Joseph, 2012). Kemunculan media menurut Chaffee \& Metzger (2018) menjadikan pemahaman tentang agenda setting telah mengalami pergeseran. Apa yang terjadi saat ini bukan lagi isu-isu apa yang disampaikan media untuk khalayak pikirkan, namun isu-isu apa yang khalayak sampaikan ke media yang ingin dipikirkan.

Hasil penelitian ini juga mengungkapkan bahwa agenda media sosial tentang hoaks dibentuk oleh para pengguna media sosial itu sendiri. Jika sebuah tema meningkat dalam kurun tertentu, misalnya tentang politik (pemilu) dikarenakan pengguna media sosial atau netizen (warganet) memiliki konsentrasi dan perhatian yang relatif sama tentang hal tersebut. Ada juga upaya dari pihak-pihak tertentu untuk memviralkan sebuah tema hoaks untuk tujuan tertentu semisal untuk menjatuhkan masing-masing kandidat presiden yang sedang bertarung dalam proses pemilu. Seperti yang didefinisikan oleh Pellegrini (2008) bahwa hoaks sebagai sebuah kebohongan yang dikarang sedemikian rupa oleh seseorang untuk menutupi atau mengalihkan perhatian dari kebenaran yang digunakan untuk kepentingan pribadi, baik itu secara intrinsik maupun ekstrinsik.

Dalam agenda setting media konvensional, dapat dikatakan bahwa apa yang dianggap penting oleh media, itu pula yang dianggap penting oleh khalayak (McCombs dan Shaw, 1972). Namun pada media sosial dapat dikatakan apa yang dianggap penting oleh netizen itu juga yang dianggap penting baik bagi netizen lainnya dan juga bagi media massa. Dalam agenda setting media sosial tidak ada yang menjadi gatekeeper. Semua arus informasi hoaks misalnya dengan mudahnya diproduksi dan menyebar luas dengan bebas yang kemudian dibagikan berkali-kali ke pengguna lainnya. Seperti yang disampaikan oleh Williams \& Delli Carpini (2004) bahwa media baru membuat informasi beredar begitu melimpah. Sudah tidak ada lagi batasan ruang dan waktu yang mendasari fungsi gatekeeper. Bahkan internet telah merevolusi jurnalisme yang selama ini memfungsikan diri sebagai gatekeeper menjadi gateway (Robinson, 2006). Media sosial dianggap mampu merepresentasikan agenda khalayak yang memiliki pengaruh terhadap agenda media. Internet tidak hanya memperluas cakupan dinamika agenda setting namun juga memperluas definisi sumber berita dan redaksi pemberitaan di dalam proses komunikasi massa (Bode, L., Sayre, B., Shah, C., Shah, D., \& Wilcox, 2010).

Begitu pula dengan konten hoaks, agenda media yang terbentuk di media sosial merepresentasikan kepentingan para netizen. Bahkan pada konten hoaks bidang kesehatan yang termasuk konten hoaks terbanyak, agenda setting media sosial yang terbangun karena netizen menganggap konten tersebut penting untuk segera diketahui oleh khalayak lainnya terlepas dari benar tidaknya konten tersebut. Laras Sekarasih dalam Respati (2017) mengatakan orang lebih cepat percaya hoaks di antaranya karena keterbatasan pengetahuan yang 
dimiliki seseorang tentang informasi yang diperoleh. Ketidaktahuan seseorang tentang informasi menyebabkan mereka terjebak dan mudah menerima dan menyebarkan hoaks.

Sifat media sosial yang memproduksi dan berbagi berita begitu mudah, ditambah dengan sifat viralnya memfasilitasi berbagi konten hoaks dengan sangat cepat dengan jangkauan yang lebih luas. Sejak 2008, media sosial telah berada di garis depan dalam menetapkan agenda konten sebuah berita atau informasi. Hal ini membuat beberapa pengamat percaya bahwa media sosial bukan lagi media alternatif seperti dulu, melainkan media arus utama dengan cara membuat berita utama. Elemen terpenting yang membuat media sosial menjadi bagian tak terpisahkan dari kehidupan sehari-hari karena memiliki sifat jejaring sosial yang mana pengguna dapat mengonsumsi konten yang dibagikan di media sosial juga dapat menghasilkan konten (Nasrullah, 2015). Karakteristik media sosial yang berjaringan, informatif, interaksi, gambaran simulasi sosial, dan isi informasi atau konten yang diproduksi oleh pengguna menjadikan media ini sebagai medium penyebaran hoaks yang paling mudah dan cepat.

Pengguna media sosial memberikan kontribusi penting untuk proses produksi berita. Konsekuensinya, agenda yang ditetapkan oleh media sosial dapat menjangkau setiap bagian dunia dengan mudah dan begitu banyak orang juga dapat memberikan kontribusi ekstra untuk memperkuat dan melegitimasi agenda virtual ini. Media sosial dapat memperoleh umpan balik simultan dari penggunanya dan ini membuatnya berguna. Selain itu, implementasi media sosial terbuka untuk penggunanya yang dapat memberikan kontribusi tambahan untuk implementasi ini.

Hal lain yang dapat disimpulkan bahwa penggunaan media sosial yang terus meningkat setiap tahun membuktikan bahwa kekuatan konsep-konsep untuk memengaruhi khalayak dan membentuk agenda khalayak. Selain itu, orang dapat melakukan kontak dengan setiap orang di setiap tempat dengan menggunakan media sosial juga telah meningkatkan efektivitas media sosial dalam menetapkan agenda khalayak. Dalam kasus penyebaran hoaks, media sosial adalah kendaraan komunikasi yang paling efektif digunakan penggunanya untuk membagikan ide, pengetahuan, dan pemikiran tentang konten tidak benar (hoaks) baik yang diproduksi sendiri maupun diterima dari orang lain. Hal ini justru memperkuat organisasi sosial, serta membentuk opini publik tentang hoaks itu sendiri yang menganggap konten atau informasi itu benar adanya. Media sosial menjadi lahan subur bagi tumbuh kembangnya hoaks dan menyebar tanpa kendali dan bisa saja masyarakat dengan mudah terpapar oleh hoaks-hoaks tersebut (Kadju, 2019).

\section{PENUTUP}

\section{Simpulan}

Ada tiga tema isu hoaks yang paling menonjol bagi khalayak yaitu politik, kesehatan, dan isu pemerintahan. Hoaks dengan tema politik paling tinggi mengingat eskalasi politik selama bulan Agustus 2018 hingga Februari 2019 sangat gencar dengan persoalan pemilu. Hoaks yang beredar pun tidak semata-mata untuk menjatuhkan Jokowi sebagai calon presiden tetapi juga sebagai pemerintah yang masih berkuasa. Menyenangkan atau tidak menyenangkan penyajian hoaks ini tergantung di kubu mana penerima pesan itu memihak kubu pendukung 01 Jokowi-Ma'ruf Amin, atau 02 Prabowo-Sandiaga Uno. Hoaks yang beredar tidak jauh dari pasangan calon presiden dan wakil presiden ini. Jika konten hoaks yang menyudutkan paslon 01, maka penyajiannya dianggap tidak menyenangkan bagi para pendukungnya begitupun sebaliknya.

Hasil penelitian ini juga mengungkapkan bahwa agenda media sosial tentang hoaks dibentuk oleh para pengguna media sosial itu sendiri. Jika sebuah tema meningkat dalam kurun tertentu seperti tentang politik (pemilu) dikarenakan pengguna media sosial atau netizen memiliki konsentrasi dan perhatian yang relatif sama tentang hal tersebut. Ada juga upaya dari 
pihak-pihak tertentu untuk memviralkan sebuah tema hoaks untuk tujuan tertentu yaitu untuk menjatuhkan masing-masing kandidat presiden. Begitu pula dengan konten hoaks, agenda media yang terbentuk di media sosial merepresentasikan kepentingan para netizen. Bahkan pada konten hoaks bidang kesehatan yang termasuk konten hoaks terbanyak, agenda setting media sosial yang terbangun karena netizen menganggap konten tersebut penting untuk segera diketahui oleh khalayak lainnya terlepas dari benar tidaknya konten tersebut. Dalam kasus penyebaran hoaks, media sosial adalah kendaraan komunikasi yang paling efektif digunakan penggunanya untuk membagikan ide, pengetahuan, dan pemikiran tentang konten hoaks baik yang diproduksi sendiri maupun diterima dari orang lain.

\section{Saran}

Perlawanan terhadap hoaks tidak semata-mata tanggung jawab pemerintah, tetapi juga dukungan dan inisiatif dari semua elemen masyarakat, seperti lembaga swasta, perguruan tinggi, NGO, dan masyarakat umum. Kolaborasi yang berkesinambungan antarlembaga sangat diperlukan untuk melawan hoaks utamanya dalam memberikan literasi dan edukasi kepada masyarakat umum tentang pengenalan hoaks. Selanjutnya inisiatif dan peran dari masyarakat sendiri penting untuk dibangun. Hal ini agar masyarakat dapat cerdas mengenal hoaks.

\section{DAFTAR PUSTAKA}

Bode, L., Sayre, B., Shah, C., Shah, D., \& Wilcox, D. (2010) Agenda Setting in a Digital Age: Tracking Attention to California Proposition8 in Social Media, Online News, and Conventional News. Policy\& Internet. 2 (1), 7-32.

Chaffee, S.H. \& Metzger, M.J. (2018) The End of Mass Communication? Refining Milestone Mass Communications Theories for the 21st Century. [Online] 4, 140-154. Available from: doi:10.4324/9781315679402-10.
Chen, Yoke Yiie, et al (2014) Email Hoax Detection System Using Levenshtein Distance Methods. Journal of Computers, 9(2). 9 (2).

Chen, Y.Y., Yong, S.-P. \& Ishak, A. (2014) Email Hoax Detection System Using Levenshtein Distance Method. Journal of Computers. [Online] 9 (2), 441-446. Available from: doi:10.4304/jep.9.2.441446.

Christiany, J. (2018). Christiany Juditha. Jurnal Pekommas. 3 (1), 31-44.

Damaris, Y. (2016) Trending Topic Twitter dala Menentukan Agenda Pemneritaan di Media Konvensional (Studi Kasus terhadap Pemberitaan di Kompas TV Periode Oktober-Desember 2015). Sripsi. Universitas Sultan Ageng Tirtayasa Banten.

Dearing, J. W., \& Rogers, E.M. (1996) Communication Concept 6: AgendaSetting. California, Sage Publication Inc.

Effendy, O.U. (2005) Ilmu, Teori dan Filsafat Komunikasi. Bandung, Citra Aditya Bakti.

Eriyanto (2011) Analisis Isi Pengantar Metodelogi untuk Penelitian Ilmu Komunikasi dan Ilmu-Ilmu Sosial Lainnya. Jakarta, Kencana Prenada Media Group.

Feezell, J.T. (2017) Agenda Setting through Social Media: The Importance of Incidental News Exposure and Social Filtering in the Digital Era. Jurnal Sagepub. 2017.

Frey, Lawrence R, dkk (1991) Investigating Communication: An Introduction to Research Methods. New Jersey, Prentice Hall.

Griffin, E. (2012) A'First Look at Communication Theory: Eight Edition. New York, Mc Graw Hill.

Juditha, C. (2018) Hoax Communication Interactivity in Social Media and Anticipation (Interaksi Komunikasi Hoax di Media Sosial serta Antisipasinya). Journal Pekommas. [Online] 3 (1), 31. Available from: doi:10.30818/jpkm.2018.2030104.

Juditha, C. (2019) Literasi Informasi Melawan Hoaks Bidang Kesehatan di Komunitas Online. Ilmu Komunikasi. 16 (1), 77-90.

Kadju (2019) Sapu Bersih Konten Hoaks dengan Mesin AIS. Majalah Kominfonext.

KBBI. (2019). Kamus Besar Bahasa Indonesia (KBBI). [Online] Available at: http://kbbi.web.id/hoaks. 
Kementerian Kominfo (2019). Kominfo Jaring 771 Konten Hoax, Mayoritas Terkait Politik. 2019.

Lichtman, M. (2010) Qualitative Research in Education: A User's Guide. 2nd Edition. California, Sage.

Masyarakat Telematika (MASTEL) (2017) Hasil survey mastel tentang wabah hoax nasional. 2017.

McCombs, M. E., \& Shaw, D. L. (1972). The Agenda Setting Function of Mass Media. The Public Opinion Quarterly, 176-182

McCombs, M. (2014) Setting the Agenda. Cambridge 2nd ed (ed.). Malden, MA, Polity Press.

Merheim, J.B. (1986) A Model Agenda Dynamic Communication Yearbook 10, Newburry. Mc Laughein (ed.). California, SAGE Publication.

Metei, S.A. (2010) Does Agenda Setting Theory Still Apply to Social Media. 2010.

Nasionalita, K. (2013) Hubungan Agenda Media dengan Media Online dengan Agenda Publik Mahasiswa(Studi Korelasi Agenda Media Online Newspaper kompas.com dengan Agenda Publik Mahasiswa Pasca Sarjana Fakultas Hukum Universitas Gadjah Mada tentang Isu Korupsi di Indonesia). Universitas Gadjah Mada.

Nasrullah, R. (2015a) Media Sosial: Perspektif Komunikasi, Budaya, dan Sosioteknologi. Bandung, Simbiosa Rekatama Media.

Nasrullah, R. (2015b) Teori Dan Riset Media Siber (Cybermedia). Jakarta Indonesia, Kencana Prenadamedia Group.

Nurudin (2009) Pengantar Komunikasi Massa. Jakarta, Rajawali Pers.

Pellegrini, L. (2008) An Argument For Criminal Hoaks. Disertasi. University of Southern California.Pratama, A. B. (2016). Ada 800 Ribu Situs Penyebar Hoaks di Indonesia. 2008.

Pertiwi, W.K. (2018) Riset ungkap pola pemakaian medsos orang Indonesia. 2018.

Pertiwi, W.K. (2017) Survei: 90 persen informasi kesehatan di medsos menyesatkan. Viva.co.id. 2017.

Prabowo, M.\& I. (2016) Trending Topics Vs Agenda-Setting:Pengaruh Trending
Topics Politik sebagai Reversed AgendaSetting dan Haluan Politik Pemilik Terhadap Berita Politik di Televisi. Jurnal Komunikasi Indonesia. V (1), 2301-9816.

Respati, S. (2017) Mengapa banyak orang mudah percaya berita 'Hoax'? 2017.

Robinson, S. (2006) Gateway or Gatekeeper: The Institutionalizationof Online News Increating an Altered Technological Authority. International Symposium on Online Journalism.. . 2006.

Romeltea (2014) Hoax Kian Populer - Ekses Kebebasan Dunia Maya. 2014.

Sakti, A.T. (2018) Hasil Riset DailySocial.id: 44\% Masyarakat Indonesia Tidak Bisa Mendeteksi Berita Hoax. 2018.

Salman, A., Mustaffa, N., Mohd Salleh, M.A. \& Ali, M.N.S. (2016) Social Media and Agenda Setting: Implications on Political Agenda. Jurnal Komunikasi, Malaysian Journal of Communication. [Online] 32 (1), 401-414. Available from: doi:10.17576/jkmjc-2016-3201-19.

Soejono \& Abdurrahman (1999) Metode Penelitian. Jakarta, PT. Rineka Cipta.

Straubhaar, Joseph, R.L. and L.D.P. (2012) Media Now: Understanding Media, Culture and Technology. Boston: Wadsworths, Cengage Learning.

Tamburaka, A. (2012) Agenda Setting Media Massa. Jakarta, PT RajaGrafindo Persada.

Vargo, C.J. \& Guo, L. (2017) Networks, Big Data, and Intermedia Agenda Setting: An Analysis of Traditional, Partisan, and Emerging Online U.S. News. Journalism and Mass Communication Quarterly. [Online] 94 (4), 1031-1055. Available from: doi:10.1177/1077699016679976.

White, D.M. (1950) Gate Keeper: A Case Study in The Selection of News. Journal Quanterly.

Williams, B.A. \& Delli Carpini, M.X. (2004) Monica and Bill All the Time and Everywhere. American Behavioral Scientist. [Online] 47 (9), 1208-1230. Available from: doi:10.1177/0002764203262344. 